\title{
CHALLENGES AND OPPORTUNITIES IN ADULT EDUCATION IN GREENLAND
}

\author{
Andreas Ahrens \\ Hochschule Wismar University of Applied Sciences: Technology, Business and Design, \\ Germany \\ Jelena Zaščerinska \\ Centre for Education and Innovation Research, Latvia \\ Ludmila Aḷeksejeva \\ Centre for Education and Innovation Research, Latvia
}

Olga Gukoviča

Centre for Education and Innovation Research, Latvia

Mihails Zaščerinskis

Centre for Education and Innovation Research, Latvia

Anastasija Aḷeksejeva

Centre for Education and Innovation Research, Latvia

\begin{abstract}
Education in Greenland is a central parameter in achieving the long-term goals of the Government in terms of providing the population with the necessary means to take up positions as skilled labour. The research aim is to implement theoretical and empirical analysis of adult education in Greenland underpinning the identification of challenges and opportunities in adult education in Greenland. The empirical study of the exploratory nature was carried out in November-December 2020. Data collection was based on document analysis as well as interview. The obtained data were processed via content analysis. Findings of the theoretical analysis allow defining challenges as externally created problem situations. The structuring content analysis allows identifying challenges and opportunities in adult education in Greenland. The summarizing content analysis reveals that adult education within the educational system in Greenland has not been properly addressed. The empirical findings allow concluding that adult education in Greenland is to be shaped in such a way that it responds to the emergent challenges. The present study has some limitations. The new research question has been formulated: What modern skills (creativity, digital skills, entrepreneurship, languages, etc) do adult learners in Greenland need most? Future research will focus the extension of the dataset.
\end{abstract}

Keywords: Adult education, challenge, development of the system of external and internal perspectives, Greenland, opportunity, problem, sustainability. 


\section{Introduction}

Greenland's economy is characterised by a very large and predominant public sector (European Commission, 2014). Fisheries and fishing industries dominate export, and there is a developing private sector which includes international mining- and oil companies (European Commission, 2014). The unemployment rate in Greenland is about 9\%. The public finances are highly dependent on the block grant allocated by Denmark as well as the association of Greenland with the EU (European Commission, 2014). Harsh weather conditions, the remote location of the island, and the necessity to import goods all contribute to a high cost of living in Greenland compared to other Nordic countries (Karsberg, 2016).

The general population in Greenland is around 57,000 inhabitants. The youth population (15 to 24 years) of Greenland is about 8979 people, which is approximately $40 \%$ of the population (MIPI, 2012). Of these, 7638 lived in cities while 1341 lived in small settlements. Around $10 \%$ of the entire Greenlandic youth population emigrates to Denmark to study or to work (MIPI, 2012). Approximately $89 \%$ of the Greenlandic population is native (Inuit), while the remaining $11 \%$ is primarily Danish (Hamilton \& Rasmussen, 2009). Most of the population lives in small cities along the west coast. Around one-fifth of the population lives in smaller settlements often with no more than 200 inhabitants, where access to healthcare, electricity, education, everyday goods and other services can be very limited or even non-existent (Grønlands statistik, 2014). Average life expectancy in Greenland is 68.6 years for men and 74.0 years for women (Nomesko, 2013). Education in Greenland is a central parameter in achieving the long-term goals of the Government in terms of providing the population with the necessary means to take up positions as skilled labour (European Commission, 2014). Education will enable more people to be selfsustaining and thus take pressure off the public sector (European Commission, 2014). Against this background, adult education in Greenland was not properly addressed.

The research aim is to implement theoretical and empirical analysis of adult education in Greenland underpinning the identification of challenges and opportunities in adult education in Greenland. The research is based on the methodology of the development of the system of the external and internal perspectives as demonstrated in Figure 1 (Ahrens, \& Zaščerinska, 2012). 

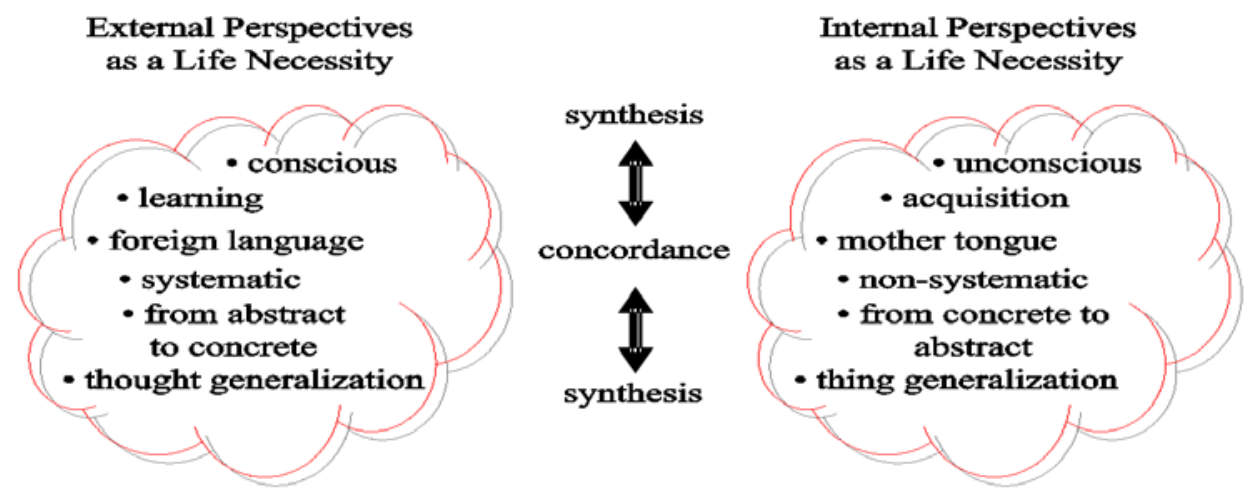

Figure 1 Development of the System of External and Internal Perspectives (Ahrens \& Zascerinska, 2012)

The research presented in the paper includes the use of theoretical as well as empirical methods. Theoretical methods imply analysis of theoretical sources and theoretical modelling (Ahrens, Zascerinska, \& Melnikova, 2019). The empirical study was of the exploratory nature. The exploratory study was aimed at generating new research questions. Data collection was based on document analysis as well as interview. The obtained data were processed via content analysis. The novel contribution of the paper is the identified challenges and opportunities in adult education in Greenland.

\section{Conceptual Framework}

Adult education in Greenland is aimed at developing individual's sustainability (European Commission, 2014). In the present research, the terms "individual", "person" and "human being" are used synonymously while the term "personality" means the combination of knowledge, skills and attitude as well as characteristics and qualities that form a person's competence and character. A sustainable personality means an adult learner who is able to develop the system of external and internal perspectives, and, in turn, the system of external and internal perspectives becomes a main condition for the sustainable personality to develop (Ahrens \& Zaščerinska, 2012).

Development and, consequently, learning (Zascerinska, 2010) is based on solving a contradiction (Čehlova, 2002, 9). Contradiction means two incompatible requirements set to one element/subject/thing/etc (Sokol, 2002, 4). Contradiction creates contradictory individual needs, namely, the necessity in change and stability (Zaščerinska \& Zaščerinskis, 2012). Contradiction is a problem situation (Ruzavin, 2005; Sokol, 2007) as well as a problem (Sorokin, 1974). 
Problem is defined to be a challenge and an opportunity (Sālsberg, 2003). In this definition, the external perspective prevails (Zaščerinska \& Zaščerinskis, 2012) as illustrated in Figure 2.

\begin{tabular}{|c|c|}
\hline External perspective & Internal perspective \\
\hline Challenge and opportunity & Gain and possibility \\
\hline \multicolumn{2}{|c|}{ The system of the external and internal perspectives } \\
\hline
\end{tabular}

Figure 2 The Definition of the Term "Problem" from the External and Internal Perspectives (the authors)

Challenge is an externally created problem situation. The authors admit that a challenge can be internally initiated. For example, a person sets a challenge of learning 10 words in English every day, or practising sport for 10 minutes twice per week. However, in the public discourse, a challenge is conventionally associated as an external phenomenon.

Development from the system perspective on the life activity includes its objective structural component determined as social and cultural aspects of development, namely, opportunities of gaining experience (Tilla, 2003). Opportunities as the objective component are the unity of two processes (Tillla, 2003):

- $\quad$ experience constructing process as the subjective aspect, and

- provision of open variable guaranteed choices of social culture learning organization.

Opportunity is defined as the development of culture of learning, education and interaction in a certain social-cultural environment gaining his/her individual's experience (Tiḷa, 2006). Opportunities for teachers to construct knowledge about the world on their own means (Maslo, 2006; Žogla, 2007) availability of social environment:

- teacher, other students are joined in implementing of a common teaching/learning task and in acquiring new knowledge in pairs or groups,

- equal relationships,

- $\quad$ activity relevant to everyone's abilities,

- teacher competence in managing co-operation,

- $\quad$ the improvement of attitudes,

- $\quad$ co-operation supports and strengthens the willingness to learn,

- $\quad$ every individual belongs to a group and is acknowledged by a group,

- the development of communication abilities: listening to the opinion, making arguments, respecting other partners of communication, and the evaluation of a joint result. 
Thus, the emphasis is laid to the objective aspect of opportunities, namely, organizing an environment for adult learners' development, where the accent has shifted towards an individual's initiated actions as a background of his/her development (Žogla, 2008) that gives the possibility for social cultural learning to precede as life activity and in that way it realizes the subjective interests of each (Tillıa, 2003).

\section{Methodology of the Empirical Study}

The design of the empirical study includes the question and purpose, sample and methodology of the empirical study. The guiding question of the empirical study was as follows: What are challenges and opportunities in adult education in Greenland? The purpose of the empirical study was to identify challenges and opportunities in adult education in Greenland.

The empirical study was carried out in November-December 2020. The present empirical study involved one respondent. The respondent's selected was impacted by two factors, namely access to the sample as well as time availability to carry out the study (Ahrens \& Zaščerinska, 2012). The qualitatively oriented empirical study allows the construction of only few respondents (Mayring, 2004). Moreover, the respondents themselves are not of interest, only the conclusions and transfers we can draw from these respondents (Flyvbjerg, 2006). Selecting the respondent for the study comprises use of informationoriented sampling, as opposed to random sampling (Flyvbjerg, 2006). This is because an average respondent is often not the richest in information. In addition, it is often more important to clarify the deeper causes behind a given problem and its consequences than to describe the symptoms of the problem and how frequently they occur (Flyvbjerg, 2006). Random samples emphasizing representativeness will seldom be able to produce this kind of insight; it is more appropriate to select some few respondents chosen for their validity. In order to save the information of the present research confidential, the respondent's name, surname and affiliation are not disclosed.

The interpretive research paradigm was used in the study. The interpretive paradigm is featured by the researcher's interest in a phenomenon. The interpretive paradigm is aimed at analysing the social construction of the meaningful reality. Meanings emerge from the interpretation. The researcher is the interpreter (Ahrens, Purvinis, Zaščerinska, Miceviciene, \& Tautkus, 2018).

The empirical study was of the exploratory nature. The exploratory study was aimed at generating new research questions. The exploratory studies are largely an inductive process to gain understanding (Edgar \& Manz, 2017). When the experimental process goes from a general theory to an understanding in specific, exploratory studies observe specific phenomena to look for patterns 
and arrive at a general theory of behaviour (Edgar \& Manz, 2017). The emphasis is on evaluation or analysis of data, not on creating new designs or models (Edgar \& Manz, 2017). The emphasis is on perspective and relative importance (Edgar \& Manz, 2017).

Data were collected via document analysis and interview. Non-structured or, in other words, unstructured interview was implemented to search for the main categories of the research field (Kroplijs \& Rascevska, 2004). Nonstructured interview is conventionally built on a certain topic to be disclosed during the meeting (Ahrens, Foerster, Zaščerinska, \& Wasser, 2020). However, non-structured interview does not imply any specific set of predetermined questions (Ahrens et al., 2020). Non-structured interview is organised in a nonformal manner and tends to be open-ended (Ahrens et al., 2020). The interview was conducted during a project preparation via international on-line meetings in November-December 2020. The interviewee was an employee who works in a fish company in Greenland. As the interview was non-structured, the topic was only defined, namely challenges and opportunities in adult education in Greenland.

Non-structured interview was studied via content analysis. Further on, content analysis included such types as (Mayring, 2000) structuring content analysis and summarizing content analysis. Structuring content analysis assists in categorising the data in accordance to the previously determined criteria (Budde, 2005). In turn, summarizing content analysis seeks to reduce the material in such a way that the essential contents are preserved, but a manageable short text is produced (Mayring, 2004, 269).

\section{Results of the Empirical Study}

The conducted interview revealed that fish industry in Greenland is the main field of work for the Greenland inhabitants. Fish industry employees are mostly unskilled. The respondent highlighted that $60 \%$ of the population in Greenland is unskilled. The respondent also pointed that about 2800 school leavers every year do not continue their education due to their poor school results. Another issue is that school education is delivered in Greenlandic but further education (vocational and higher) is in Danish. The fish companies plan to decrease the number of one-skill workers in three further years. Employee skills' recognition is important for companies in Greenland. Employee skills' recognition serves as a tool for his/her self-esteem. The respondent emphasized that in Greenland people are isolated in remote areas.

The document analysis reveals that previously, the level of education achieved and the percentage of educated people in Greenland had been low compared to other Nordic countries (Norden, 2014). A large part of the 
educational institutions focus on maritime training and education, which often attracts more men than women (Bennike, Faber, \& Nielsen, 2016). Among the Greenlandic population aged 25-74, more men have achieved some level of education than women but more women than men achieve the highest level of education (Bennike et al., 2016). Women indicated that they wanted to move to gain better access to education, to get access to more culture and leisure activities and to get away from social control in the smaller communities and provide increased opportunities for their children (Bennike et al., 2016). The study showed that men in Greenland, in contrast, are more motivated by opportunities in the labour market (Bennike et al., 2016). A reason for Greenlandic men to choose to move could be that they feel that there are better and more business opportunities for them and/or their partner elsewhere (Bennike et al., 2016). Common for respondents from both sexes in the Mobility Study was that they wanted to reside in an area where the wages are higher, with increased opportunities for public transportation and a variety of other public benefits, for example, health and education facilities (Rasmussen, 2010).

The Government has maintained a clear and concrete focus on education and training since 2002. Language teaching is highly prioritised in the teaching plans. It is the intention of the teaching that the learners become functionally bilingual (Greenlandic and Danish) and able read, write, speak and understand English (European Commission, 2014). However, the policy regarding vocational education and training also includes provision of courses from a monolingual Greenlandic perspective in order to accommodate students who do not speak Danish (European Commission, 2014). University level studies will generally require proficiency in English as well given the international nature of the academic environment and the fact that many educations are not available purely in Greenlandic or Danish (European Commission, 2014).

The Ministry of Education, Culture, Research and Church has published a National Strategy for Education 2014 (Bennike et al., 2016). Focal areas in the 2014 strategy include (Bennike et al., 2016)

- $\quad$ strengthening lowering the age of students starting education,

- $\quad$ improving the skills of personnel,

- $\quad$ reducing drop-out rates,

- $\quad$ improving guidance and counselling for students (including therapy),

- improving students' information and communication technology skills,

- $\quad$ evaluation of intervention effects.

There has been a remarkable rise in the number of active students and students completing their education in Greenland as a result of interventions related to the strategy (Bennike et al., 2016). As part of the new national strategy for education, a national centre for student counselling has been set up in Nuuk, 
and the centre now trains school counsellors all over Greenland (Bennike et al., 2016).

Specific issues in relation to education, work, recreation, population flows and identity in the Nordic region's peripheral/remote areas are summarized in five themes (Bennike et al., 2016):

1. Lack of/limited access to education in peripheral areas.

2. Restructuring of the labour markets in the peripheral areas.

3. Women find life in peripheral areas less attractive.

4. Labour supply is too narrow in the peripheral areas.

5. The stigma of the peripheral areas affects the youth of both sexes.

Globalisation and the financial crisis have put traditional male occupations under pressure (Bennike et al., 2016). The women in remote areas demand more education and employment opportunities as well as a wider range of culture and leisure activities (Bennike et al., 2016).

Lack of/limited access to education in peripheral areas is described by the problem of increased demands and expectations of formal education as well as gender-segregated education choices (Bennike et al., 2016). This increased demand for formal education is related to the fact that today even traditional jobs within for instance agriculture and fishing requires a different set of skills than in the past, including knowledge of economics, management, security, etc (Bennike et al., 2016). Possible areas for action include (Bennike et al., 2016)

- Decentralization of educational institutions,

- $\quad$ Long-distance learning,

- Focusing on transportation/commuting,

- $\quad$ Special assistance to young people who have to move far.

Long-distance education in remote areas can have a positive effect in relation to discouraging emigration among young people, while keeping their attachment to the local areas (Bennike et al., 2016). Additionally, long-distance learning can contribute to educating the local population to ensure that skills are present in relation to undertaking new jobs in upcoming sectors, such as within the health care system, which is generally growing at the local level in all the Nordic countries (Bennike et al., 2016).

\section{Findings of the Empirical Study}

The structuring content analysis of the collected data allows identifying challenges and opportunities in adult education in Greenland. Table 1 presents the findings of the empirical study. 
SOCIETY. INTEGRATION. EDUCATION

Proceedings of the International Scientific Conference. Volume IV, May $28^{\text {th }}-29^{\text {th }}, 2021.19-29$

Table 1 Challenges and Opportunities in Adult Education in Greenland (the authors)

\begin{tabular}{|c|c|}
\hline \multicolumn{2}{|c|}{ Adult education in Greenland } \\
\hline Challenges & Opportunities \\
\hline $\begin{array}{ll}\text { - } & \text { Population migration, } \\
\text { - } & \text { Gender issues, } \\
\text { - } & \text { Peripheral issues, } \\
\text { - } & \text { Commuting, } \\
\text { - } & \text { Labour market restructuring from } \\
& \text { traditional occupations to modern ones } \\
& \text { (economics, management, security, etc) }\end{array}$ & $\begin{array}{ll}\text { - } & \text { Establishment of adult education } \\
\text { (purpose, task, activities, etc) in the } \\
\text { country’s educational system } \\
\text { - } \quad \begin{array}{l}\text { Development of adult education } \\
\text { institutions }\end{array} \\
\text { - } \quad \text { Building of adult educators' capacity } \\
\text { - } \quad \text { Design of training programmes for } \\
\text { diversification of adult learners' skills: } \\
\text { from one skill (maritime, fishery, } \\
\text { agriculture, etc) to the modern skills } \\
\text { (creativity, digital skills, } \\
\text { entrepreneurship, languages, etc) } \\
\text { - } \quad \text { Development of digital adult education } \\
\text { - }\end{array}$ \\
\hline
\end{tabular}

Source: The authors.

The summarizing content analysis reveals that adult education within the educational system in Greenland has not been properly addressed.

\section{Conclusions}

Findings of the theoretical analysis allow defining challenges as externally created problem situations. The empirical findings allow concluding that adult education in Greenland is to be shaped in such a way that it responds to the emergent challenges. The practical application of the model of problem, as illustrated in Figure 2, within the implemented empirical study allows concluding that the model is valid.

The present study has some limitations. A limitation is participation of only one respondent in the conducted interview. Another limitation is that only few documents and research publications on education in Greenland were detected via search machines (google).

The new research question has been formulated: What modern skills (creativity, digital skills, entrepreneurship, languages, etc) do adult learners in Greenland need most? More respondents could be involved in the study at once. The validation of the problem model by the analysis of the inputs and outputs of problem solving as well as expert evaluation is proposed. 
Ahrens et al., 2021. Challenges and Opportunities in Adult Education in Greenland

\section{References}

Ahrens, A., Foerster, M., Zaščerinska, J., \& Wasser, I. (2020). European Accreditation Agency's View on Kazakhstan's Engineering and Information Technology Higher Education. SOCIETY. INTEGRATION. EDUCATION Proceedings of the International Scientific Conference. Volume V, 15-25. DOI: 10.17770/sie2020vol1.4861.

Ahrens, A., Purvinis, O., Zaščerinska, J., Miceviciene, D., \& Tautkus, A. (2018). Burstiness Management for Smart, Sustainable and Inclusive Growth: Emerging Research and Opportunities. IGI Global, p. 226. DOI: 10.4018/978-1-5225-5442-4.

Ahrens, A., Zascerinska, J., \& Melnikova, J. (2019). Method for the Construction of Students' Scientific Identity within English for Academic Purposes: The Case of International Students of Master Programme "Information and Electrical Engineering” at Hochschule Wismar. SOCIETY. INTEGRATION. EDUCATION. Proceedings of the International Scientific Conference, Rezekne, Rezekne Academy of Technologies, Volume I, Higher Education, 43-53. DOI: http://dx.doi.org/10.17770/sie2019vol1.3731.

Ahrens, A., \& Zaščerinska, J. (2012). Sustainable Development in Engineering Education: A Pedagogical Approach. In: Stasys Vaitekunas (Ed), ATEE Spring University 2012 Conference 20 Years of Sustainable Development: Learning from Each Other, Lithuanian University of Educational Sciences, 115-130. Klaipeda: Klaipeda University.

Ahrens, A., Zaščerinska, J. (2014). Factors that Influence Sample Size in Educational Research. 2014 ATEE Spring University proceedings Changing Education in a Changing Society, 19-32. Published by Klaipeda University, Lithuania. ISSN 18222196.

Bennike, K.B., Faber, S.T., \& Nielsen, H.P. (2016). Gender, Education and Population Flow Summary report on knowledge, cross-Nordic experiences and examples from practice. Nordic Council of Ministers 2015. http://dx.doi.org/10.6027/TN2016-514

Budde, R. (2005). Mexican and Central American L.A. Garment Workers: Globalized Industries and their economic constraints. LIT Verlag Münster.

Čehlova, Z. (2002). Izziñas aktivitāte mācībās. Rīgā: RaKa.

Edgar, Thomas W., \& Manz, David O. (2017). Chapter 3 - Starting Your Research, Editor(s): Thomas W. Edgar, David O. Manz, Research Methods for Cyber Security, Syngress, 2017, Pages 63-92. Elsevier Inc. https://doi.org/10.1016/B978-0-12-805349-2.00003-0.

European Commission. (2014). Programming Document for the Sustainable Development of Greenland 2014-2020 (2014/137/EU). Retrieved from https://ec.europa.eu/ transparency/regdoc/rep/3/2014/EN/C-2014-6775-F1-EN-ANNEX-1-PART-1.PDF

Flyvbjerg, B. (2006). Five Misunderstandings About Case-Study Research. Qualitative Inquiry, 12 (2), 219-245.

Grønlands statistik. (2014). Greenland in Figures 2014. Retrieved from http://www.stat.gl/publ/da/GF/2014/pdf/Greenland\%20in\%20Figures\%202014.pd

Hamilton, C., \& Rasmussen, R.O. (2009). Population, Sex Ratios and Development in Greenland. Arctic, 62:1.

Karsberg, S. (2016). Mental health among youth in Greenland. Who is responsible? What is being done? Nordic Centre for Welfare and Social Issues. NordPub. Retrieved from http://norden.diva-portal.org/smash/record.jsf?pid=diva2\%3A1071163\&dswid=3937

Kroplijs, A., \& Rascevska, M. (2004). Kvalitatīvās pētniecības metodes sociālajās zinātnēs. Rīga: RaKa, pp. 178. 
Mayring, P. (2000). Qualitative Content Analysis. Forum Qualitative Sozialforschung / Forum: Qualitative Social Research, 1(2), Art. 20.

Mayring, P. (2004). Qualitative Content Analysis. In: U. Flick, E. Von Kardoff and I. Steinke (Eds.), A Companion to Qualitative Research, pp. 266-269. SAGE, UK, Glasgow.

Maslo, I. (2006). In I. Maslo (Ed.) No zināšanām uz kompetentu darbību. Latvijas Universitātes Akadēmiskais apgāds, pp. 148-161.

MIPI. (2012). Nøgletal om børn og unge i Grønland 2011. Retrieved from http://mipi.nanoq.gl/Emner/e\%20Udgivelser/ /media/mipi/MIPIs_udgivelser/Nøgletal \%20om\%20Børne\%20og\%20Unge\%20\%20\%20grunddel\%202011\%20\%20\%20KAL \%20og\%20DK.ashx

Nomesko. (2013). Health Statistics for the Nordic Countries, 2013. Retrieved from https://norden.diva-portal.org/smash/get/diva2:941584/FULLTEXT01.pdf

Norden. (2014). Nordic Statistical Yearbook 2014. Retrieved from http://norden.divaportal.org/smash/record.jsf?pid=diva2\%3A763002\&dswid=-7870

Rasmussen, R. O. (2010). In O. Rasmussen (Ed.) Mobilitet i Grønland: Sammenfattende analyse. Stokholm: NordRegio.

Ruzavin, G.I. (2005). Problemnaja situacija kak virazhenie protivorechija $v$ razvitiinauchnogo poznanija // Protivorechie i diskurs. M.: IF RAN.

Sālsberg, P. (2003). Problēmu risināšana un mācīsanās skolā. Skolotāja rokasgrāmata: aktīvas mācību metodes un demokrātiskas skolas veidošana. R.: Rīgas skolotāju izglītības centrs.

Sokol, A. (2002). The Thinking Approach. Introductory Information. Retrieved from www.thinking-approach.org.

Sokol, A. (2007). Development of Inventive Thinking in Language Education. Synopsys of the PhD Thesis. University of Latvia.

Sorokin, N.A. (1974). Didaktika. Izdateljstvo „Posveshenie“ Moskva.

Tillla, I. (2003). Development of adolescents' social culture competence within the second foreign language studies. Synopsys of the $\mathrm{PhD}$ Thesis. Riga: University of Latvia, 24-42.

Tiḷı,a, I. (2006) Sociālkultūras mācīšanās konstruktīvistiskā. In I. Maslo (Ed.), No zināšanām uz kompetentu darbību, 161-170. Latvijas Universitātes Akadēmiskais apgāds,.

Zaščerinska, J. (2010). Professional Environment for Teacher Professional Development. Proceedings of 5th International scientific conference Theory for Practice in the Education of Contemporary Society of Riga Teacher Training and Educational Management Academy, 25 - 27 March, 2010, Riga, Latvia, 2010, 396-402.

Zaščerinska, J., \& Zaščerinskis M. (2012). Problem Solving in Student Police Officers' Professional Development. Proceedings of the I International scientific conference „Legal, Sociological and Psychological Aspects of Human Safety” of State Police College, January 28th, 2011, Riga, Latvia, 251-262.

Žogla, I. (2007). Didaktika humānpedagogijāa. Latvijas Universitātes Pedagogiijas un psihologiijas fakultātes ,Augstskolu didaktika: mūsdienu teorija un prakse” kursa lekcija 2007. gada 12. februārī.

Žogla, I. (2008). Teachers as Researchers in the Era of Tests. ATEE Spring University Conference Teacher of the 21st Century: Quality Education for Quality Teaching, Riga, University of Latvia, 25-40. 